as president of the Prehistoric Society in 1937, and occupies no less than 175 pages in quarto of that Society's recently published Proceedings for 1937 $(3,2)$.

\section{Royal Geographical Society: Medals and Awards}

H.M. THE KING has approved the award of the Royal Medals as follows: Founder's Medal to $\mathrm{Mr}$. John Rymill, for his organization and leadership of the British Graham Land Expedition 1934-37; Patron's Medal to Mr. Eric Shipton, for his explorations around Nanda Devi and Mount Everest and his conduct of the Shaksgam Expedition of 1937. The Council has made the following awards: Victoria Medal to Mr. A. R. Hinks, for his contributions to the study of geodesy and the figure of the earth, map projections, and photogrammetric survey ; Murchison Grant to Mr. Martin Lindsay, for his journey across Greenland in 1934 ; Back Grant to Mr. Thomas Hay, for his contributions to the physical geography of the Lake District ; Cuthbert Peek Grant to Mr. Bradford Washburn, for his explorations and glacier studies in Alaska; Gill Memorial to Mr. Ivan Champion, for his explorations and surveys in Papua.

\section{The British Association and Australia}

The Australian Government has decided not to proceed further at present with the proposal to invite the British Association to meet again in the Commonwealth. As it is desired, however, that leading men of science should from time to time be afforded opportunity to visit Australia, it has been decided to issue invitations to a party of six to attend the jubilee meeting of the Australian and New Zealand Association for the Advancement of Science at Canberra in January 1939. It is hoped that the precedent so set will become regular practice at each succeeding biennial meeting of the Association. A grant of $£ A 1,500$ towards the expenses of the guests in 1939 has been promised by the Government.

\section{Man and Animals in Great Britain}

A MEETING arranged by the University of London Animal Welfare Society (ULAWS) was held in the Beveridge Hall of the University of London on March 22 to discuss "Man's Relation to Nature and his Response" with reference to "the Survey and Regulation of British Fauna". The chairman, Sir P. Chalmers Mitchell, said that the so-called 'balance of Nature' is a myth and has not existed since glacial times, when there were no animals in Britain to be balanced. We interfere too much for there to be one and interference is no good without knowledge. The Marquess of Tavistock showed how conflicting interests make legislation difficult. Fruit farmers and the owners of grouse moors oppose the protection of bullfinches and peregrine falcons respectively. There is no need to fear the introduction of wild birds for, unlike alien rodents, they find competition too strong. As regards method of control, there is no difficulty in shooting deer in the Highlands, but in the wooded Lowlands hunting is kinder. Shooting is often unkind to foxes owing to the uncertainty of aim. Otters are neutral in sporting streams, killing some game fish but keeping down eels; but they are harmful in trout hatcheries and to ormamental wild fowl. Protecting stoats and weasels to keep rabbits down is a fallacy. Prof. F. A. E. Crew referred to the need for research on the ecology of British mammals; he suggested that we should have something like the U.S. Biological Survey, that the Bureau of Animal Population should be supported, and the staffs of museums and university departments should be enlarged. Sir Roy Robinson, chairman of the Forestry Commission, said that complaints about his treatment of animals were sentimental and not based on knowledge. Rabbits should be exterminated. There are too many deer and foxes. The only mammal in need of protection is the pine marten, and he would like to harbour them. All birds, except black-game and caper-cailzie, should be encouraged in forests. Other speakers referred to the desirability and the difficulties of rabbit extermination in various parts of Great Britain.

\section{Roman Fortifications in Yorkshire}

Recent evidence of the varied methods of construction adopted by the builders of Hadrian's Wall (see Nature, March 19, p. 505) lent additional interest to the account of the defensive system of Roman Aldborough, near Boroughbridge, Yorkshire, which was presented to the Society of Antiquaries on March 24 by Mr. J. N. L. Myres and Miss Mary Kitson Clarke. This site, known to the Romans as Isurium Brigantium, was the capital city of the British tribe of the Brigantes, an important people, whose territory covered nearly the whole of the northern part of what is now England south of the Border. The excavation was carried out by $\mathrm{Mr}$. Myres and Miss Clarke for the Roman Antiquities Committee of the Yorkshire Archæological Society. In the course of the excavation, it was found that the north-west wall did not run as shown in the Ordnance Survey map, but that its angle lay farther to the north-west. The main scheme of the defences, it was found, consisted of the wall itself, backed by a bank of clay and sand. This, however, was not constructed until the second century A.D. Previously there appears to have been no system of defence, and Roman occupation had been haphazard. Later, perhaps in the early part of the fourth century, a large bastion had been added to the angle, and at least one small bastion built on to the west wall, not far from the angle. Still preserved to a height of nine feet in parts is the lower story of an internal angle tower, which was a striking feature of the wall in its original form. This had supported some structure rising above the wall. Pottery indicates that a lean-to hut at the back of the tower was occupied in the third century. The excavations will be carried further in the coming season.

\section{Clifton College Scientific Society}

The Clifton College Scientific Society held a conversazione in the Science School on Thursday, March 17. About 350 guests were present, as well 
as approximately the same number of members of the Society, but the spacious laboratories were not more than pleasantly full. Among the exhibits and experiments, arranged by the boys themselves, were a cathode ray oscillograph, a model geyser, fluorescence in ultra-violet light, a model of a hydraulic ram, the preparation of artificial silk, Bristol's share in the development of chemistry, chemiluminescence, flames and explosions, the effect of plant hormones, living elvers from the Severn, and experiments upon animal respiration. Lectures upon colour and upon liquid oxygen, with demonstrations, were given by two members of the Society, and a third entertained visitors by chemical conjuring performed to the accompaniment of an almost professional patter. The aeronautical section-a comparatively new but already vigorous branch of the Society-staged a topical exhibit of aeroplane parts, including a collection of bombs, while in the Science Library were displayed many scientific classics and autographs of famous men of science. Some of the original quartz glass, made by W. A. Shenstone while at Clifton, was on exhibit in one of the corridors, where a collection of the elements, arranged by a former member of the Society when still at school, also attracted much attention. One of the most popular features of the evening was a tableau vivant of Lavoisier and his wife, after the well-known picture by David. Among the guests were Sir John Inskip, Profs. M. W. Travers, W. E. Garner, C. M. Yonge, R. J. Brocklehurst, A. Rendle Short and A. M. Tyndall, Air Commodore Dalzell-McKean, and the head masters and science masters of many neighbouring schools.

\section{Acquisitions at the British Museum (Natural History)}

The British Museum (Natural History) has received as a donation from Lord Sudeley the skins of three Colobus monkeys from Mount Kenya, Colobus polykomos kikuyuensis. One of the specimens is of exceptional interest, being nearly a full albino, the only black hairs remaining being a few scattered hairs on the back and a small V-shaped marking on the crown of the head. These specimens came from close to Nanyuki, situated on the equator on the western slopes of Mt. Kenya at an elevation of about 8,000-9,000 ft. These white or semi-white Colobus monkeys apparently belong to one family group, as they are all found in one very restricted locality on Mt. Kenya. Lord Sudeley shot the specimens himself and reports that the eyes were of normal colour and not the eyes of an albino. Lord Moyne has presented to the Museum the zoological collections made by M. J. Delacour and Mr. J. S. Colman during the recent cruise of his yacht Rosaura. These include material from the coast of Greenland, southwards to the West Indies, Brazil and the coast of West Africa. The collection when worked out will probably prove of prime importance for several distinct branches of zoological inquiry. The Royal Society has presented a set of specimens of the volcanic rocks of Montserrat in the West Indies, collected by Mr. A. G. MacGregor, who was a member of the Royal Society Expedition which visited the island in 1936 to investigate the causes of the recent earthquake activity and its relation to the vulcanology. A piece of meteoric iron, found last year at Kumerina in Western Australia, has been presented by the Public Library, Museum and Art Gallery at Perth. A polished specimen of 'Brazilian onyz', an ophicalcite worked in the Argentine, has been presented by Messrs. John Bolding and Sons, and the Cookson Lead and Antimony Company has presented a remarkably fine specimen of metallic antimony crystals.

\section{Rubber Technology Conference}

A Rubber Thahnology Conference, under the auspices of the Institution of the Rubber Industry, has been arranged to take place in London on May 23-25, under the honorary presidency of Sir William Bragg. The Conference is being supported by the leading organizations connected with the rubber producing and manufacturing industries and by many other scientific and technical societies; altogether, some seventy organizations in Great Britain, Canada, South Africa, British Malaya, Ceylon, the United States, Austria, Belgium, France, Germany, Holland, Italy and Poland will be sending official delegates to the Conference. These include the Research Association of British Rubber Manufacturers and many of the other industrial research associations operating under the Department of Scientific and Industrial Research. More than seventy papers have already been promised from authors representing most of the countries just mentioned. This excellent response promises to make the Conference an outstanding event, at which a notable gathering of rubber technologists and scientific men interested in rubber from at home and over-seas is expected. A special feature of the Conference will be a symposium on methods of improving and evaluating the durability of rubber, but all other aspects of rubber science and technology will be covered by the remaining sessions. An attractive programme of social events, visits, etc., is being arranged. Those desiring to become members of the Conference or to contribute papers can obtain full particulars from the Secretary, Institution of the Rubber Industry, 12 Whitehall, London, S.W.1.

\section{Oil in Osage County, Oklahoma, U.S.A.}

A FIrid party of the United States Geological Survey has recently investigated sub-surface geology of the Osage Indian Reservation of Oklahoma, and it appears that there are many localities in this Reservation worthy of exploration from the point of view of oil production. Prior to the issue of the Geological Survey's report, a paper had been written by N. W. Bass, W. R. Dillard, and J. H. Hengst (U.S. Department of the Interior. Bull. 886, A) describing several of these localities. In the east. central part of the Reservation, it is believed there may be an oil pool of considerable extent in the Bartesville Sand. Three productive wells have already been drilled. One drilled thirteen years ago had produced 63,000 barrels of oil by the end of (Continued on p. 599) 